\title{
Erratum to: Variability of European beech wood density as influenced by interactions between tree-ring growth and aspect
}

Daniela Diaconu*, Marc Wassenberg and Heinrich Spiecker

Erratum to: Forest Ecosystems 2016, 3:6 DOI:

\subsection{6/s40663-016-0065-8}

Following publication of the original version [1] of the article in Forest Ecosystem, it was brought to our attention that in the PDF file, Equation 1 is not presented correctly on page 3 .

It should be presented like the following:

$$
\mathrm{y}_{i}=\alpha_{1}+\alpha_{2} \cdot \text { Aspect }_{i}+\alpha_{3} \cdot \text { TRW }+\alpha_{4} \cdot \mathrm{CA}+\alpha_{5} \cdot \text { Aspect }_{i}: \text { TRW }+\alpha_{6} \cdot \text { Aspect }_{i}: \text { CA }+ \text { Tree }+ \text { Year }
$$

Received: 3 March 2016 Accepted: 4 March 2016

Published online: 18 March 2016

\section{Reference}

1. Diaconu et al (2016) Variability of European beech wood density as

influenced by interactions between tree-ring growth and aspect.

Forest Ecosyst 3:6

Convenient online submission

- Rigorous peer review

- Immediate publication on acceptance

- Open access: articles freely available online

- High visibility within the field

- Retaining the copyright to your article

Submit your next manuscript at springeropen.com

\section{包 Springer}

(c) 2016 Diaconu et al. Open Access This article is distributed under the terms of the Creative Commons Attribution 4.0 International License (http://creativecommons.org/licenses/by/4.0/), which permits unrestricted use, distribution, and reproduction in any medium, provided you give appropriate credit to the original author(s) and the source, provide a link to the Creative Commons license, and indicate if changes were made. 